\title{
Psychological study of environmental colors (1): Effects of color lighting on the performance of simple task (1)
}

\author{
Shin'ya Takahashi (146826a(a)nucc.cc.nagoya-u.ac.jp) \\ [Nagoya University]
}

\author{
環境色彩の心理学的研究（1）——色照明が単純作業成績に及ぼす効果— \\ 高橋 晋也 \\ 名古屋大学環境学研究科
}

\section{要約}

人間の心理および行動に及ぼす環境色彩の効果を検討した。赤、緑、青、黄の 4 種類の色照明下で、のべ 160 名の被験 者にクレペリン型の連続加算課題を行わせ、課題成績の他、被験者自身八の影響（身体的疲労感、精神的疲労感、眠気、 集中力）、経過時間推定、色照明に対する印象（SD 尺度評定）等を分析した。実験の結果、色照明はそれぞれ特徽的な 印象（赤一“快活”、青一“鮮麗”、緑・黄一“平榣”）を喚起したが、課題成績に関しては、作業の生産性・安定性・正 確性のいずれの指標においても色の効果はなかった。時間推定については、すべての条件で過小評価となったが、やは り色条件による差はなかった。被験者への影響に関しては、緑条件において他の条件よりも精神的疲労感が低くなる傾 向が示された。また、色条件をつぶした上で、各色照明に対する「好きな」項目の評定值と課題成績との相関を見たと ころ、照明色を「好き」と評定した被験者ほど作業の生産性と正確性が高くなる傾向が示された。これらの実験結果に 基べき、古くから関心が持たれてきた色彩の心理的効用について、その科学的検証における理論的な問題点と、安易な 現場応用に対する批判などが議論された。

\section{Key words}

environmental color, color lighting, performance of simple task

\section{Introduction}

The psychological effect of color is of a practical as well as theoretical interest. In various places, some specific colors are used with the aim of improving human performance. For example, recently, the color of a running track that was traditionally reddish brown became changed to blue in some sports grounds in Japan because of the expectation that blue would enhance athletes' concentration and help them make good records (Kobe Shinbun, 1998). However, it seems that such application of colors goes too far ahead of a scientific knowledge, so the importance of a theoretical study of color psychology is more and more increasing.

So far, a large number of psychological studies of the effect of color have been made. Such studies could be classified into two categories in terms of the treatment of color; i.e., visual stimulus or one of environmental factors. The former analyzed the change in subjects' psychological or physiological states when they were required only to see color paper or stay under color lighting without doing any other works, whereas the latter focused on the indirect effects of environmental colors on the unrelated behaviors or the task performances.

Many studies have investigated the effects of color as a visual stimulus from the past (Lewinski, 1938; Goldstein, 1942; Wilson,
1966; Jacobs \& Hustmyer, 1974; Jacobs \& Suess, 1975). For example, Wilson (1966) made his subjects observe red or green slides projected on a screen, and found that red induced more arousing response than green on GSR data. More recently, Omori et al. (2002) analyzed psychological and physiological effects of color stimuli and found that a large stimulus of pure red or purpleblue and a small stimulus of pure yellow-red or bright blue made observers feel rested and comfortable. Most of this kind of studies were motivated by generally-accepted assumption (or belief) that the long-wavelength colors (red and yellow) are more arousing than the short-wavelength colors (blue and green). Based on this idea, for instance, it was argued that high arousal caused by red facilitates subjects' time lapse perception (Smets, 1969) or enhances their hand grip strength (Green, et al., 1982; O'Connell, et al., 1985). However, these studies were sometimes criticized to be lacking an appropriate control of stimulus brightness (Kaiser, 1984; Davidoff, 1991; Valdez \& Mehrabian, 1994). Moreover, not a few evidences against "red-arousing / blue-calming" assumption have been reported (Fanger, et al., 1977; Greene \& Bell, 1980; Caldwell \& Jones, 1985; Ingram \& Lieberman, 1985). Now the issue is still controversial.

On the other hand, the effects of color as one of the environmental factors have not been studied enough so far. A few studies have investigated the effects of color on the unrelated behaviors or the task performances. Considering practical problems, how- 
ever, the effect of environmental color would have more importance than that of color stimulus, because it is rather unusual in daily life to see color without doing any other works. In order to obtain the desired effects of environmental colors in various places such as an office, a factory, a shop, or a private room, it is necessary to know what and how much effect would be produced by the color as one of the environmental factors. Consequently, in this study, I varied the color of lighting during simple task and examined the effects it would produce on the task performance and subjects' mental states.

\section{Methods}

\subsection{Subjects}

A hundred and sixty undergraduates ( 81 males and 79 females) participated as subjects. They were divided into four groups each of which was assigned to one of four color lighting conditions; red, green, blue, and yellow.

\subsection{Instruments}

Color beam bulbs (National BF110V80W-R, -G, $-\mathrm{B},-\mathrm{Y}$ ) were used to illuminate an experimental room. In each color lighting condition, five color beam bulbs were turned on (Figure 1) and the voltage was controlled via slidac so that the brightness of the room did not change among color conditions. Illuminance at the top of a table on which subjects performed the task was set at 440 lux in all color lighting conditions and in white lighting control condition (illuminated by white fluorescent lamps). CIE 1931 (x,y) chromaticity coordinates measured at the same location were (.668, $.320),(.330, .570),(.140, .201),(.537, .430)$ in red, green, blue, and yellow lighting conditions respectively, and $(.374, .389)$ in control condition.

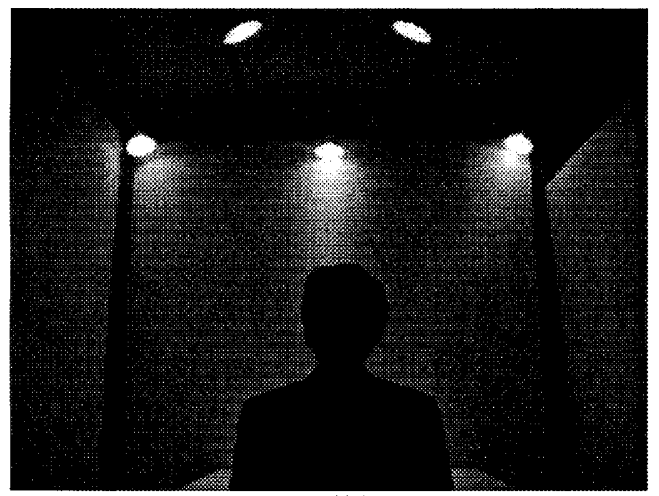

Figure 1: An experimental room illuminated by five color beam bulbs

\subsection{Task}

Kraepelin-type addition task was used. Subjects added adjoining two numbers as quickly and accurately as possible. Changing the line every 40 seconds, the task was continued for 440 seconds (11 lines). Subjects were not informed about such time setting in advance.

\subsection{Procedure}

All subjects repeated the task twice, first under the white lighting (control condition), second under the color lighting (red, green, blue, or yellow; experimental condition). Between the tasks, subjects rested for few minutes with their eyes closed. After finishing the second task, they were asked to answer the questionnaire. Total time of the experiment was approximately 30 minutes. All subjects were tested individually.

\subsection{Questionnaire}

The questionnaire was composed of three parts. Part 1 asked subject to estimate the time he/she spent on the second task under the color lighting, and also to judge the relative length of the second task compared with the first task under the white lighting. Part 2 asked about subject's physical fatigue, mental fatigue, sleepiness, and concentration on 4-point scales. Part 3 was a series of SD (semantic differential) scales asking about the impression of color lighting under which he/she did the second task. It included 30 pairs of antonymic adjectives such as "heavy-light," "old-new," "soft-hard," "cold-warm," and "weak-strong" (see Table 4 for full items employed).

\section{Results}

\subsection{Task performance}

Four indices of the task performance were analyzed; (1) averaged amount of addition per unit time (40 seconds), (2) standard deviation of the amounts of addition per unit time, (3) averaged difference between amounts of addition in sequential two lines, and (4) total number of error answers. Averaged amount is an index of productivity of the work, standard deviation and averaged difference are negative indices of stability of the work (higher score indicates lower stability), and total error is a negative index of accuracy of the work (higher score indicates lower accuracy). In order to eliminate individual differences of the absolute task performance and clarify the effects of color lighting, the data obtained in the color lighting condition were transformed into relative values compared with the data obtained in the white lighting condition in each subject. ${ }^{(2)}$

Table 1 shows the results of these indices (actual data and relative values) in each condition. A one-way analysis of variance (ANOVA) was conducted for relative values in each index, and it was revealed that effect of color condition was not significant in all indices (averaged amount, $F<1$; standard deviation, $F=1.62$, $p<.20$; averaged difference, $F<1$; total error, $F<1$; $d f \mathrm{~s}=3,156$ ). Although the tendency would be read in Table 1 that subjects in green and yellow conditions did the task at steadier pace than subjects in red and blue conditions (i.e., lower relative value of standard deviation and averaged difference in green and yellow conditions than in red and blue conditions), the differences were 
not statistically supported probably because of large SDs of the data (.472 for standard deviation and .651 for averaged difference in all subjects' data).

Table 1: Results of task performance in each color condition (actual data in a first row and relative values in a second row of each index)

\begin{tabular}{|c|c|c|c|c|c|c|c|c|}
\hline & \multicolumn{2}{|c|}{ Red } & \multicolumn{2}{|c|}{ Green } & \multicolumn{2}{|c|}{ Blue } & \multicolumn{2}{|c|}{ Yellow } \\
\hline & White & Color & White & Color & White & Color & White & Color \\
\hline \multirow{2}{*}{ Averaged anount } & 38.78 & 41.85 & 39.87 & 42.73 & 41.75 & 44.55 & 38.47 & 41.28 \\
\hline & \multicolumn{2}{|c|}{1.081} & \multicolumn{2}{|c|}{1.074} & \multicolumn{2}{|c|}{1.069} & \multicolumn{2}{|c|}{1.078} \\
\hline \multirow{2}{*}{ Standard deviation } & 3.36 & 3.87 & 3.52 & 3.61 & 3.42 & 4.02 & 3.51 & 3.70 \\
\hline & \multicolumn{2}{|c|}{1.242} & \multicolumn{2}{|c|}{1.104} & \multicolumn{2}{|c|}{1,304} & \multicolumn{2}{|c|}{1.129} \\
\hline \multirow{2}{*}{ Averaged difference } & 3.18 & 3.85 & 3,25 & 3.45 & 3.38 & 3.80 & 3.31 & 3.42 \\
\hline & \multicolumn{2}{|c|}{1,380} & \multicolumn{2}{|c|}{1.168} & \multicolumn{2}{|c|}{1.249} & \multicolumn{2}{|c|}{1.185} \\
\hline \multirow{2}{*}{ Total error } & 1.88 & 1.63 & 2.85 & 1.98 & 2.45 & 2.33 & 1.58 & 1.68 \\
\hline & \multicolumn{2}{|c|}{-0.25} & \multicolumn{2}{|c|}{-0.88} & \multicolumn{2}{|c|}{-0.13} & \multicolumn{2}{|c|}{0.10} \\
\hline
\end{tabular}

\subsection{Time estimation}

Table 2 shows the results of time estimation. The upper part shows mean and SD (in parentheses) of estimated time, and the lower part shows number of subjects who answered that time of the task under color lighting was shorter than, same as, or longer than the task under white lighting, in each color condition. As for mean estimated time, subjects in all color conditions tended to underestimate the time that was actually 440 seconds, but no significant difference was found among color conditions $(F<1)$. Apparently mean estimated time in green and yellow conditions seems to be shorter than those in red and blue conditions, but these differences were not significant. It is obviously due to the large SDs of data. In fact, some subjects estimated the time at 60 seconds ( 1 minute), and some estimated it at 900 seconds ( 15 minutes).

Also, the color of lighting did not influence the judgment of relative length of the task under color lighting compared with the task under white lighting $\left(\chi^{2}=2.45, d f=6\right.$, n.s. $)$.

Table 2: Results of time estimation in each color condition

\begin{tabular}{|c|c|c|c|c|c|}
\hline & & Real & (inen & Blue & Yollow \\
\hline \multicolumn{2}{|c|}{$\begin{array}{c}\text { Estimuled time (in second) } \\
\text { *SD in parentheses }\end{array}$} & $\begin{array}{r}359.6 \\
(162,6)\end{array}$ & $\begin{array}{c}327.1 \\
(167.4)\end{array}$ & $\begin{array}{c}363.4 \\
(225.8)\end{array}$ & $\begin{array}{r}328.1 \\
(155.7)\end{array}$ \\
\hline \multirow{3}{*}{$\begin{array}{l}\text { Comparison with } \\
\text { white lighting } \\
\text { condition } \\
\text { (Number of } \\
\text { subjects) }\end{array}$} & Sharter & 13 & 12 & 15 & 17 \\
\hline & Same & 18 & 20 & 18 & 14 \\
\hline & Longer & 9 & 8 & 7 & 9 \\
\hline
\end{tabular}

\subsection{Influence on subjects' physical and mental states}

Subject's physical fatigue, mental fatigue, sleepiness, and concentration were measured on 4-point scales; 0 (none) - 3 (very). Table 3 shows the results. Subjects in green condition, which is often regarded as a healing color, tended to report less mental fatigue $(F=2.27, d f=3,156, p<.10)$. Similar tendencies were also found in physical fatigue and sleepiness, but effects could not reach at a significance (physical fatigue, $F<1$; sleepiness, $F=$ $1.79, p<.20 ; d f \mathrm{~s}=3,156)$. Subjects' concentration on the task was not influenced by the color of lighting $(F<1)$.

Table 3: Results of subjects' physical and mental states in each color condition (SD in parentheses)

\begin{tabular}{l|c|c|c|c}
\hline & Red & Green & Blue & Yellow \\
\hline Physical fatigue & $1.88(0.69)$ & $1.65(0.92)$ & $1.88(0.85)$ & $1.83(0.84)$ \\
\hline Mental fatigue & $1.28(0.85)$ & $1.00(0.82)$ & $1.40(0.81)$ & $1.45(0.90)$ \\
\hline Sleepiness & $1.30(0.88)$ & $1.17(0.75)$ & $1.53(0.91)$ & $1.55(0.88)$ \\
\hline Concentration & $1.95(0.71)$ & $2.05(0.50)$ & $2.10(0.63)$ & $2.08(0.47)$ \\
\hline
\end{tabular}

\subsection{Impression of color lightings}

A factor analysis was conducted, using a principal component analysis for factor extraction and a varimax rotation, on the impression ratings of color lightings. Judging from a decrement of the Eigenvalues, I obtained three factors which explained $53.2 \%$ of a total variance (Table 4). The items such as "relieved" and "relaxed" had high factor loadings on the first factor, so it was labelled as calmness. The items such as "lively" and "vigorous" had high factor loadings on the second factor, so it was labelled as cheerfulness. The items such as "sharp," "hard," and "clear" had

Table 4: Factor loadings of each item employed in the SD scales (after varimax rotation)

\begin{tabular}{|c|c|c|c|c|}
\hline Employed items & Factor I & Factor II & Factor III & Cormmmality \\
\hline Iritated - Relieved & .818 & -.019 & .027 & 670 \\
\hline Unrelaxed - Relaxed & .805 & .138 & -.044 & 669 \\
\hline Bad - Good & .762 & -.148 & -.189 & .638 \\
\hline Obtrusive - Temperate & .760 & .416 & -.042 & .752 \\
\hline Oppressive - Not Oppressive & .700 & .147 & -.002 & .512 \\
\hline Restless - Restfiul & .681 & .152 & .477 & .715 \\
\hline Unfamiliar - Familiar & .677 & -.430 & .179 & .676 \\
\hline Dislike - Like & .669 & -.074 & -.192 & .490 \\
\hline Ugty - Beautiful & .547 & .023 & -.462 & .513 \\
\hline Unusual - Usual & .450 & -.090 & .090 & .218 \\
\hline Heavy - Light & .414 & -.138 & -.141 & .210 \\
\hline Disordered - Ordered & .335 & -.007 &.- .162 & .138 \\
\hline Lonely - Lively & .045 & .828 & .005 & 688 \\
\hline Dounhearted - Vigorous & .041 & .807 & .136 & .672 \\
\hline Sad - Happy & -.136 & .668 & -.131 & .482 \\
\hline Dark - Bright & -.167 & .654 & .136 & .474 \\
\hline Sober - Loud & .321 & .646 & .211 & .565 \\
\hline Static - Dynamic & .531 & .551 & -.223 & 635 \\
\hline Unreliable - Reliable & -.061 & .525 & .379 & 423 \\
\hline Unpleasant - Pleasant & -.272 & .510 & .242 & .393 \\
\hline Weak - Strong & .393 & .446 & .432 & .540 \\
\hline Dull - Sharp & .006 & .211 & .799 & .683 \\
\hline Soft - Hard & .276 & -.224 & .698 & .614 \\
\hline Unclear - Clear & -.452 & -.054 & .673 & .661 \\
\hline Warm - Cold & -.183 & -.550 & .610 & .707 \\
\hline Not vivid - Vivid & -.144 & .265 & .576 & .423 \\
\hline Old - New & -221 & .095 & .575 & 388 \\
\hline Tender - Severe & .553 & -.179 & .573 & .665 \\
\hline Unrefined - Refined & -.035 & .125 & .569 & .340 \\
\hline Vague - Distinct & -.034 & .394 & .495 & .402 \\
\hline Eigenvalue & 6.57 & 5.42 & 3.98 & \\
\hline Variance explained $(\%)$ & 21.59 & 16.10 & 15.51 & \\
\hline
\end{tabular}


high factor loadings on the third factor, so it was labelled as refinedness. Then, mean of ratings on 12 items (from "relieved" to "ordered" in Table 4; reliability coefficient ( $\alpha$ ) was .877), on 9 items (from "lively" to "strong" in Table 4; $\alpha$ was .828), and on 9 items (from "sharp" to "distinct" in Table 4; $\alpha$ was .812) were calculated in each subject to make calmness score, cheerfulness score, and refinedness score, respectively.

Figures 2 (a)-(c) show the mean scores of calmness, cheerfulness, and refinedness in each color condition. One-way ANOVAs revealed that there was a significant main effect of color condition in all factor scores (calmness, $F=8.93$; cheerfulness, $F=21.04$; refinedness, $F=28.28 ; d f \mathrm{~S}=3,156, p \mathrm{~s}<.001$ ). Post-hoc comparison by Tukey HSD clarified that calmness was significantly lower, and cheerfulness was significantly higher, in red condition than in other three conditions. As for refinedness, differences between every comparisons except for red and green were significant; i.e., blue $>$ red and green $>$ yellow $(p s<.05) .{ }^{(3)}$

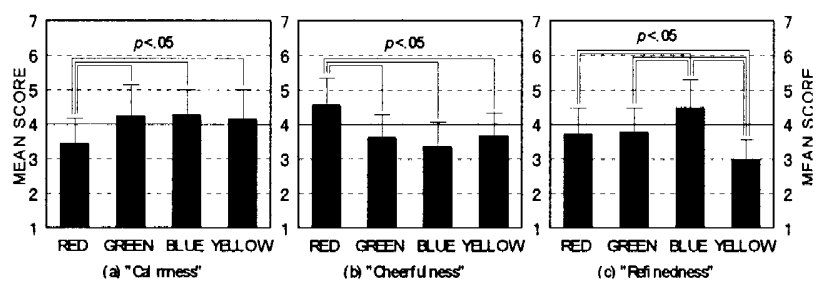

Figure 2: Mean scores of each of three factors in each color condition

\subsection{Correlation between indices}

Table 5 shows correlation coefficients between indices analyzed above; four task performance indices (relative values), estimated time, four indices of subjects' physical and mental states, and three factor scores of impression of color lightings.

Table 5: Correlation coefficients between indices

$$
\left({ }^{* *} p<.01,{ }^{*} p<.05, \uparrow p<.10\right)
$$

\begin{tabular}{|c|c|c|c|c|c|c|c|c|c|c|c|}
\hline & $\mathrm{A}_{\mathrm{a}}$ & Sd & Ad & $\mathrm{Te}$ & E & Pr & M & s & $\mathrm{c}$ & Calm & Ohar \\
\hline Avraged amourt (Aa) & - & & & & & & & & & & \\
\hline Standad deviaion (Sd) & .090 & - & & & & & & & & & \\
\hline Averged differnes (Ad) & -016 & $62^{* *}$ & - & & & & & & & & \\
\hline Total encr (Te) & $-.231 \div$ & .075 & 066 & - & & & & & & & \\
\hline Estimaed ine $(\mathrm{E})$ & $\infty \times 0$ & $.184^{*}$ & .106 & .051 & - & & & & & & \\
\hline Prysical fatigne (R1) & 010 & -.007 & 007 & .664 & .090 & - & & & & & \\
\hline Mental faxiguc (M) &.$\infty 0$ & -128 & 0.36 & .118 & $-\infty 13$ & $.317 * *$ & - & & & & \\
\hline Sloppiness (S) & -043 & 1697 & 000 & 101 & 047 & .115 & $474 *$ & - & & & \\
\hline Concentration (C) & .130 & .104 & 000 & $\begin{array}{l}-.019 \\
\end{array}$ & -.071 & .095 & -.012 & -046 & - & & \\
\hline Calmess (Calm) & .010 & -044 & 025 & $\begin{aligned}-135^{\circ} \\
\end{aligned}$ & -.065 & $-203^{* * *}$ & $-.274 * t$ & $151^{\dagger}$ & $153^{\dagger}$ & - & \\
\hline Oherfulness (Cherr) & -.056 & -.096 & -015 & .665 & .054 & .026 & .029 & -.079 & .077 & $-159 *$ & $\vdots-$ \\
\hline Redinathess & .025 & $(x) 4$ & -659 & -.107 & .034 & -.108 & -.101 & $\begin{array}{l}-.124 \\
\end{array}$ & .090 & .105 & $.162^{*}$ \\
\hline
\end{tabular}

First, among task performance indices, averaged amount negatively correlated with total error, indicating there was not a speed- accuracy trade off; i.e., subjects with more improvement on work productivity in the second task also improved their work accuracy. Strong positive correlation between standard deviation and averaged difference has no importance, since they are similar indices of work stability.

Next, estimated time had a positive correlation with standard deviation, indicating that subjects who performed the second task with more stability compared with the first task tended to answer shorter time in time estimation.

Indices of subjects' physical and mental states had no correlation with task performance indices. Within the indices, on the other hand, mental fatigue positively correlated with physical fatigue and sleepiness, while concentration did not correlate with other indices.

Finally, as for the factor scores of impression of color lightings, calmness showed the strongest correlations with other indices. It had negative correlations with physical fatigue, mental fatigue, and sleepiness, and had a positive correlation with concentration, suggesting that lighting condition with more calm impression was generally good for subjects. And, indeed, calmness also negatively correlated with total error. Within indices, there was a negative correlation between calmness and cheerfulness, and a positive correlation between refinedness and cheerfulness.

\section{Discussion}

In the present study, the effects of the color of lighting upon task performance and other indices including time estimation, subjects' physical and mental states, and impression of color lightings were analyzed. The effects on the task performance could be regarded as overt effects and the effects on other indices could be regarded as covert effects, since the task performance, as a final output to the experimental requirement, would be influenced by the color lightings in the way that subjects' psychological states mediate between color and performance. For instance, if subjects in one condition felt stronger fatigue than subjects in another condition and both showed the same task performance, then we can consider that covert effect was there but overt effect was not. The evaluation of such results would depend on the standpoint of view. In some social situations, where the results of work is only called in question, it may have no meanings. However, at least psychologically, it does have an importance.

To summarize the results of this experiment according to the viewpoint discussed above, color lightings produced covert effects to some extent but did not produce any overt effects. The clearest effect was observed on the impression of color lightings themselves. As shown in Figure 2, red lighting made the least calm and the most cheerful impression, blue lighting made the most refined impression, and yellow lighting made the least refined impression. (Green lighting seems to lack a distinct characteristics, though it made a relatively calm impression.) Moreover, it was shown that subjects' mental fatigue tended to be weaker in 
the green condition than in other conditions (Table 3). Despite these covert effects, however, task performance was not influenced by the color lightings. In other words, subjects in all color conditions finally achieved the task with the same productivity, the same stability, and the same accuracy regardless of the nature of impression given by each color lighting or the fatigue they felt.

Two possible explanations could be addressed on these results. First, as Davidoff (1991) argued, the environmental colors might be able to have the effects only upon the response bias of subjects, and the widely-held assumption (or expectation) about the direct relationship between color and human behavior is unfounded. Indeed, it might be the case. However, there is another possibility, though partly sharing the same argument as Davidoff's, to be considered that the effect of environmental colors does exist, but its nature is not universal; i.e., it depend largely on the other environmental and subjective factors such as a kind of work, the way of evaluating the performance, or subject's color preference. This view would pose a serious problem to a theoretical consideration of the color effect as well as the practical use of colors. If, for example, some positive effects were produced by the individually preferred colors no matter what they were, then should we call it "the effect of the color?" The author's answer is "no." Rather, it should be regarded as "the effect of good feelings" created by the preferred color. And such effect would be brought about in the same way by other environmental factors such as a preferred music, a preferred fragrance, and so on. In this case, we may have no reason for calling it the peculiar effect of color.

To examine the above-discussed explanation, I reanalyzed the data in terms of the relationship between subjects' preference of the color lightings and the task performance indices. Correlations between the rating value on "dislike-like" item of SD scales and four performance indices and four indices of subjects' physical and mental states were calculated. As the results, subjects' degree of "liking" of the color lighting had a positive correlation with averaged amount $(r=.133, p<.10)$ and a negative correlation with total error $(r=-.163, p<.05$ ), suggesting that subjects who did the second task under the preferred color lightings showed more improvement on the task productivity and accuracy. In addition, the degree of liking correlated negatively with subjects' mental fatigue $(r=-.248, p<.01)$ and sleepiness $(r=-.178, p<$ $.05)$, and positively with their concentration $(r=.147, p<.10)$. These results would support the assumption that the environmental color has both the covert effect on subjects' mental states and the overt effect on the task performance depending on the preference of colors by subjects, not on the specific nature of colors, at least in the case of such a simple task as one used in this study.

Finally, as for time estimation, no remarkable effect was produced by the color lightings in this experiment. Also, it had no correlation with the degree of liking of color lightings discussed just above. As mentioned in the introduction, several previous studies have focused on the effect of color on time estimation. However, the available results are contradictory. Smets (1969) showed that subjects estimated the time they spent watching red to be shorter than the time with same length ( 45 seconds) they spent watching blue. Contrarily, Caldwell \& Jones (1985), using a counting task, showed that subjects' time estimation was not different between red and blue lighting conditions. Furthermore, results of my preliminary experiment showed that time estimation tended to be shorter in blue lighting condition than in red lighting condition. And we have the result of the present study (Table 2). It is almost impossible to put these results together to draw a valid conclusion about the effect of color on time estimation, but at least we can point out one thing; subjects' time estimation must be influenced by the various factors other than the environmental colors, such as their self-evaluation of the task performance, the actual time they spent, and the way of asking by the experimenter (whether informed in advance or not). Thus, it is necessary to control these factors and evaluate the possible effects of the environmental colors as purely as possible.

\section{Conclusion}

Four colors of lighting, red, green, blue, and yellow, made the characteristic impressions on subjects, and also it was shown that subjects in green condition felt weaker mental fatigue than subjects in other conditions. However, colors of lighting did not have the effect on the task performance, nor on the time estimation. Subjects in all conditions did the task with the same productivity, the same stability, and the same accuracy despite the possible internal (covert) changes caused by the color lightings. Rather, it was suggested that subjects' preference of the lighting color, not the kind of colors, more strongly influenced both their mental states and the task performance. From another point of view, it might be the case that such a simple task as one used in this study was not appropriate for an exact evaluation of possible effects of the color lightings. In such task, subjects might be able to devote themselves to a required work regardless of the strong impression given by the color lightings. Therefore, it is also necessary to employ more cognitive task in the future studies.

The effect of the environmental colors is indeed an attractive topic to both researchers and designers, so it is necessary to accumulate an accurate knowledge in order to obtain the desired effect. Too much amplified discussion and hasty application should be refrained.

\section{Notes}

(1) This study was supported by a Grant-in-Aid for Scientific Research, Ministry of Education, Science, and Culture of Japan, No.15206063, to Satoru Kuno (Nagoya University). And a part of this study was presented at AIC2003 (mid-term meeting of the International Color Association) held in Bangkok, in August 2003.

(2) Averaged amount, standard deviation, and averaged difference were transformed into the ratio between two values. Total error was trans- 
formed into the difference between two values. For example, a relative value " 1.2 " of averaged amount means $20 \%$ increase, and a relative value " -3 " of total error means decrease of three errors.

(3) A part of these results are not necessarily in conformity with the consensus on what is called color affection. Such disagreement would be due to the difference between objects to be examined; the color of lighting in this study, and usually color paper in the color affection studies. For example, yellow is generally said to be "gay" and "dynamic," but the yellow lighting in this study made rather "calm" and "tender" impression, probably because its perceived strength of color was weaker than other color lightings. Nevertheless, the impression of red, green, and blue lightings roughly agreed with the previous findings of color affection studies.

\section{References}

Caldwell, J. E. \& Jones, G. E. 1985 The effects of exposure to red and blue light on physiological indices and time estimation Perception, 14, 19-29.

Davidoff, J. 1991 Cognition through color. Cambridge, MA: The MIT Press.

Fanger, P. O., Breum, N. O., \& Jerking, E. 1977 Can color and noise influence man's thermal comfort? Ergonomics, 20, 1118.

Goldstein, K. 1942 Some experimental observations concerning the influence of color on the function of the organism. Occupational Therapy, 21, 147-151.

Green, W. K., Hasson, S. M., Mohammed, S. K., Phillips, C. L., Richards, P. E., Smith, M. E., \& White, A. 1982 Effect of viewing selected colors on the performance of gross and fine motor tasks. Perceptual and Motor Skills, 54, 778.

Greene, T. C. \& Bell, P. A. 1980 Additional considerations concerning the effects of "warm" and "cool" colors on energy conservation. Ergonomics, 23, 949-954.

Ingram, F. \& Lieberman, L. R. 1985 Effects of expectancy on the performance of hand grip after viewing selected hues. Perceptual and Motor Skills, 61, 370.

Jacobs, K. W. \& Hustmyer, F. E. 1974 Effects of four psychological primary colors on GSR, heart rate, and respiration rate. Perceptual and Motor Skills, 38, 763-766.

Jacobs, K. W. \& Suess, J. F. 1975 Effects of four psychological primary colors on anxiety state. Perceptual and Motor Skills, 41, 207-210.

Kaiser, P. K. 1984 Physiological response to color: A critical review. Color Research and Application, 9, 29-36.

Kobe Shinbun 1998 (an evening edition on 7 Nobember) "Magic carpet" making a good record. [in Japanese]

Lewinski. R. J. 1938 An investigation of individual responses to chromatic illumination. The Journal of Psychology, 6, 155160 .

O'Connell, B. J., Harper, R. S., \& McAndrew, F. T. 1985 Grip strength as a function of exposure to red or green visual stimulation. Perceptual and Motor Skills, 61, 1157-1158.

Omori, M., Hashimoto, R., \& Kato, Y. 2002 Relation between psychological and physiological responces on color stimulus. Journal of the Color Science Association of Japan, 26, 50-63. [in Japanese with English abstract]

Smets, G. 1969 Time expression of red and blue. Perceptual and Motor Skills, 29, 511-514.

Valdez, P. \& Mehrabian, A. 1994 Effects of color on emotions. Journal of Experimental Psychology: General, 123, 394-409.

Wilson, G. D. 1966 Arousal properties of red versus green. Perceptual and Motor Skills, 23, 942-949.

(受稿 : 2005 年 6 月 10 日 受理 : 2005 年 6 月 25 日) 